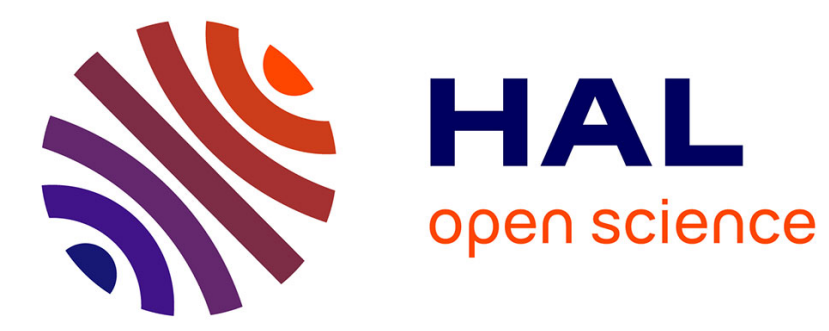

\title{
Rickettsial genomics and the paradigm of genome reduction associated with increased virulence
}

\author{
Awa Diop, Didier Raoult, Pierre-Edouard Fournier
}

\section{To cite this version:}

Awa Diop, Didier Raoult, Pierre-Edouard Fournier. Rickettsial genomics and the paradigm of genome reduction associated with increased virulence. Microbes and Infection, 2018, 20 (7-8, SI), pp.401-409. 10.1016/j.micinf.2017.11.009 . hal-01935051

\section{HAL Id: hal-01935051 https://hal.science/hal-01935051}

Submitted on 10 Apr 2019

HAL is a multi-disciplinary open access archive for the deposit and dissemination of scientific research documents, whether they are published or not. The documents may come from teaching and research institutions in France or abroad, or from public or private research centers.
L'archive ouverte pluridisciplinaire HAL, est destinée au dépôt et à la diffusion de documents scientifiques de niveau recherche, publiés ou non, émanant des établissements d'enseignement et de recherche français ou étrangers, des laboratoires publics ou privés. 


\title{
Rickettsial genomics and the paradigm of genome reduction associated with increased virulence
}

\author{
Awa Diop ${ }^{\mathrm{a}}$, Didier Raoult ${ }^{\mathrm{a}, \mathrm{b}}$, Pierre-Edouard Fournier ${ }^{\mathrm{a}, *}$ \\ ${ }^{a}$ Aix-Marseille Université, Institut Hospitalo-Universitaire Méditerranée-Infection, URMITE, UM63, CNRS 7278, IRD 198, Inserm U1095, Assistance \\ Publique-Hôpitaux de Marseille, 19-21 Boulevard Jean Moulin, 13005 Marseille, France \\ ${ }^{\mathrm{b}}$ Campus International UCAD-IRD, Dakar, Senegal
}

Received 22 August 2017; accepted 15 November 2017

Available online 27 December 2017

\begin{abstract}
Rickettsia species are arthropod endosymbiotic $\alpha$-proteobacteria that can infect mammalian hosts during their obligate intracellular lifecycle, and cause a range of mild to severe diseases in humans. Paradoxically, during their adaptation to a bottleneck lifestyle, rickettsial genomes have undergone an evolution marked by a progressive chromosomic and plasmidic degradation resulting in a genome reduction from 1.5 to $1.1 \mathrm{Mb}$, with a coding capacity of $69-84 \%$. A striking finding of rickettsial genomics has been that the most virulent species had genomes that were drastically reduced and degraded when compared to closely related less virulent or nonpathogenic species. This paradoxical evolution, which is not unique to members of the genus Rickettsia but has been identified as a convergent evolution of several major human pathogenic bacteria, parallels a selected loss of genes associated with transcriptional regulators, but with a high preservation of toxin-antitoxin (TA) modules and recombination and DNA repair proteins. In addition, these bacteria have undergone a proliferation of genetic elements, notably short palindromic elements, whose role remains unknown. Recent proteomic and transcriptomics analyses have revealed a differential level or degradation of gene expression that may, at least partially, explain differences in virulence among Rickettsia species. However, future investigations are mandatory to provide novel insights into the mechanisms by which genomic reductive evolution contributes to an emergence of pathogenesis. (C) 2017 Institut Pasteur. Published by Elsevier Masson SAS. All rights reserved.
\end{abstract}

\section{Introduction}

The genus Rickettsia (order Rickettsiales, family Rickettsiaceae) is currently made of obligate intracellular $\alpha$-proteobacteria mostly associated to arthropods worldwide $[1,2]$. These bacteria can also infect mammalian hosts, mostly through arthropod bites or feces, and were initially phylogenetically classified into two major groups on the basis of their pathogenicity for humans. These groups include the spotted fever group (SFG) that currently contains 16 pathogenic agents (Table 1) causing spotted fevers, as well as numerous species of as-yet unknown pathogenicity, associated with

\footnotetext{
* Corresponding author. Fax: +33413732 402 .

E-mail address: pierre-edouard.fournier@univ-amu.fr (P.-E. Fournier).
}

ticks, fleas and mites; and the typhus group (TG) that is made of Rickettsia prowazekii and Rickettsia typhi causing typhus and associated with human body lice and rat fleas, respectively. However, the SFG group was later demonstrated to be divided into distinct phylogenetic subgroups on the basis of gene sequence comparisons [3-5]. Rickettsia species cause a range of mild to severe diseases, the most common being scalp eschar and neck lymphadenopathy (SENLAT), also named tick-borne lyphadenopathy (TIBOLA) or Dermacentor-borne necrosis, erythema and lymphadenopathy (DEBONEL), murine typhus, Mediterranean spotted fever (MSF), Rocky Mountain spotted fever (RMSF), and epidemic typhus [6-8]. In addition to spotted fever and typhus group rickettsiae, two species, Rickettsia bellii and Rickettsia canadensis, associated with ticks but not causing to date any recognized human 
Table 1

Classification, vectors, reservoirs and diseases of Rickettsia species with known pathogenicity to humans.

\begin{tabular}{|c|c|c|c|c|c|}
\hline Antigenic group & Species & Strain_name & Rickettsiosis & Vector & Reservoirs \\
\hline \multirow[t]{17}{*}{ Spotted fever group } & R. aeschlimannii & MC16 & Rickettsiosis & Ticks: Hyalomma m. sp. & Unknown \\
\hline & R. africae & ESF-5 & African tick-bite fever & $\begin{array}{l}\text { Ticks: Amblyomma } \\
\text { variegatum }\end{array}$ & Ruminants \\
\hline & R. akari & Hartford & Rickettsialpox & $\begin{array}{l}\text { Mites: Allodermanyssus } \\
\text { sanguineus }\end{array}$ & Mice, rodents \\
\hline & R. australis & Cutlack & Queensland tick typhus & Ticks: Ixodes sp. & Rodents \\
\hline & R. conorii & Malish 7 & Mediterranean spotted fever & Ticks: Rhipicephalus sp. & Dogs, rodents \\
\hline & R. felis & URRWXCal2 & Flea spotted fever & Flea: Ctenocephalides felis & Cats, rodents, opossums \\
\hline & R. heilongjiangensis & 054 & $\begin{array}{l}\text { Far Eastern tick borne } \\
\text { rickettsiosis }\end{array}$ & Ticks: Dermacentor silvarum & Rodents \\
\hline & R. helvetica & C9P9 & $\begin{array}{l}\text { Aneruptive fever/Unnamed } \\
\text { rickettsiosis }\end{array}$ & Ticks: Ixodes ricinus & Rodents \\
\hline & R. honei & $R B$ & $\begin{array}{l}\text { Flinders Island spotted fever, } \\
\text { Thai tick typhus }\end{array}$ & Ticks: Aponomma hydrosauri & Rodents, reptiles \\
\hline & R. japonica & $Y H$ & $\begin{array}{l}\text { Japanese spotted fever or } \\
\text { Oriental spotted fever }\end{array}$ & Ticks: Haemaphysalis sp. & Rodents \\
\hline & R. massiliae & MTU5 & Mediterranean spotted fever & Tck: Rhipicephalus turanicus & Unknown \\
\hline & R. parkeri & Portsmouth & Unnamed rickettsiosis & Ticks & Rodents \\
\hline & R. raoultii & Khabarovsk & $\begin{array}{l}\text { scalp eschar and neck } \\
\text { lymphadenopathy (SENLAT) }\end{array}$ & Ticks: Dermacentor sivarum & Unknown \\
\hline & R. rickettsii & Sheila Smith & Rocky Mountain spotted fever & Ticks: Dermacentor sp. & Rodents \\
\hline & R. sibirica & 246 & $\begin{array}{l}\text { North Asian tick typhus, } \\
\text { Siberian tick typhus }\end{array}$ & Ticks: Dermacentor sp & Rodents \\
\hline & R. sibirica & HA-91 & $\begin{array}{l}\text { Lymphangitis-associated } \\
\text { rickettsiosis }\end{array}$ & Ticks: Dermacentor sp. & Rodents \\
\hline & R. slovaca & $13-\mathrm{B}$ & $\begin{array}{l}\text { scalp eschar and neck } \\
\text { lymphadenopathy (SENLAT) }\end{array}$ & Ticks: Dermacentor sp. & Lagomorphes, rodents \\
\hline \multirow[t]{3}{*}{ Typhus group } & R. prowazekii & Breinl & $\begin{array}{l}\text { Epidemic typhus, Brill-Zinsser } \\
\text { disease }\end{array}$ & Louse: Pediculus humanus & Humans, flying squirrels \\
\hline & R. prowazekii & Rp22 & Epidemic typhus & Louse: Pediculus humanus & Humans, flying squirrels \\
\hline & R. typhi & Wilmington & Murine typhus & Fleas: Xenopsylla cheopis & Rodents \\
\hline
\end{tabular}

disease, diverged early from these two groups. Furthermore, recent studies have reported the association of other Rickettsia lineages with other reservoirs including protozoa, algae, leeches plants or insects $[4,9,10]$.

In 1995, the complete genome sequencing of Haemophilus influenzae (the first sequenced genome) [11] marked the beginning of the genomic era. Over the past two decades, the completion of the genome sequences of most Rickettsia species, starting with that of $R$. prowazekii, allowed better knowledge about the molecular mechanisms involved in their pathogenicity [12] (see Fig. 1).

\section{Characteristics and genome architecture of Rickettsia species}

Rickettsia species have genome sizes ranging from 1.1 to 2.3 Mbp and exhibit a G + C content of 29-33\% (Table 2). Rickettsia hoogstraalii and Rickettsia endosymbiont of Ixodes scapularis [13] have the largest genomes sequenced to date but exhibit no known pathogenic effects. Rickettsial genomes are also characterized by a high degree of synteny (Fig. 2) [4] despite the presence of numerous pseudogenes and a large fraction of non-coding DNA, reaching $24 \%$ in $R$. prowazekii $[14,15]$. This genomic degradation likely results from their endosymbiotic lifestyle that has allowed them to discard genes involved in metabolisms supplied by their eukaryotic host cells $[16,17]$. This genomic downsizing has occurred through a progressive gene degradation, from complete functional genes to functional pseudogenes to non functional pseudogenes to gene remnants to discarded genes [18-21]. Generally, rickettsial genomes are typical of those of symbiotic bacteria, which are obligate intracellular and are characterized by a reduced genome, relatively small, made of a single circular chromosome, evolving slowly, and maintaining a near perfect colinearity between species [22]. However, in parallel to this reduction phenomenon, rickettsial genomes exhibit a paradoxical expansion of genetic elements, including plasmids, short palindromic elements named rickettsia palindromic elements (RPEs) [23], ankyrin and tetratricopeptide repeats, toxin-antitoxin modules, ADP-ATP translocases, type IV secretion system (T4SS), as well as sca, spoT, proP and ampG genes. Moreover, the presence of plasmids in Rickettsia genomes was first detected in Rickettsia felis, demonstrating that these bacteria were able to exchange genetic material by conjugation, a mechanism that was thought to be absent from obligate intracellular and allopatric bacteria [16,17,24]. To date, 20 plasmids have been identified in 11 species, some species having 1 to 4 distinct plasmids [25-27]. 
Table 2

Main characteristics of rickettsial genomes available in Genbank.

\begin{tabular}{|c|c|c|c|c|c|c|c|c|}
\hline Species & Strain & $\begin{array}{l}\text { Genome } \\
\text { size (Mbp) }\end{array}$ & $\begin{array}{l}\mathrm{G}+\mathrm{C} \\
\text { content }(\%)\end{array}$ & Presence of plasmid (s) & $\begin{array}{l}\text { Protein-coding } \\
\text { genes }\end{array}$ & $\begin{array}{l}\% \text { coding } \\
\text { sequences }\end{array}$ & $\begin{array}{l}\text { Rickettsia } \\
\text { palindromic } \\
\text { elements }\end{array}$ & $\begin{array}{l}\text { Chromosome } \\
\text { accession } \\
\text { number }\end{array}$ \\
\hline R. aeschlimannii & MC16 & 1.31 & 32.2 & Plasmid 1, Plasmid 2 & 1051 & - & - & CCER01000000 \\
\hline R. africae & ESF-5 & 1.28 & 32.4 & pRaf & 1219 & 78.26 & - & СР001612 \\
\hline R. akari & Hartford & 1.23 & 32.3 & & 1259 & 77.4 & - & СР000847 \\
\hline R. amblyommatis & Ac37 & 1.46 & 32.4 & pRAMAC 18, pRAMAC23 & 1511 & - & - & NZ_CP012420 \\
\hline R. amblyommatis & $\mathrm{AcPa}$ & 1.44 & 32.4 & & 1123 & - & - & LANR01000001 \\
\hline R. amblyommatis & Darkwater & 1.44 & 32.8 & & 1060 & - & - & LAOH01000001 \\
\hline R. amblyommatis & GAT-30V & 1.48 & 32.4 & pMCE1, pMCE2, pMCE3 & 1550 & - & - & NC_017028 \\
\hline " $R$. argasii" & T170-B & 1.44 & 32.3 & & 1187 & - & - & LAOQQ01000006 \\
\hline R. asembonensis & NMRCii & 1.36 & 32.3 & pRAS01 & 1212 & - & - & JWSW01000001 \\
\hline R. australis & Phillips & 1.32 & 32.2 & pRau01 & 1099 & - & - & AKVZ01000001 \\
\hline R. australis & Cutlack & 1.33 & 32.3 & pMC5_1 & 1136 & - & - & NC_017058 \\
\hline R. bellii & RMLAn4 & 1.54 & 31.6 & & 1311 & - & - & LAOI01000001 \\
\hline R. bellii & RMLMog & 1.62 & 31.5 & & 1336 & - & - & LAOJ01000001 \\
\hline R. bellii & OSU 85-389 & 1.52 & 31.6 & & 1476 & - & - & NC_009883 \\
\hline R. bellii & RML369-C & 1.52 & 31.7 & & 1429 & $85.2 \%$ & 525 & NC_007940 \\
\hline $\begin{array}{l}\text { R. endosymbiont of } \\
\text { Ixodes scapularis }\end{array}$ & REIS & 1.82 & 33.0 & $\begin{array}{l}\text { pReis1, pReis2, pReis3, } \\
\text { pReis4 }\end{array}$ & 2309 & - & - & $\mathrm{CM} 000770$ \\
\hline R. canadensis & CA410 & 1.15 & 31.1 & & 1016 & - & - & NC_016929 \\
\hline R. canadensis & McKiel & 1.16 & 31.1 & & 902 & $75.2 \%$ & - & NC_009879 \\
\hline R. conorii & Malish 7 & 1.27 & 32.4 & & 1227 & 81.5 & 559 & NC_003103 \\
\hline R. conorii & A-167 & 1.26 & 32.5 & & 1210 & - & - & AJUR01000001 \\
\hline R. conorii & ITTR & 1.25 & 32.4 & & 1157 & - & - & AJHC01000001 \\
\hline R. conorii & ISTT CDC1 & 1.25 & 32.5 & & 1200 & - & - & AJVP01000001 \\
\hline $\begin{array}{l}R . \text { endosymbiont of } \\
\text { Ixodes pacificus }\end{array}$ & Humboldt & 1.56 & 32.2 & & 1294 & - & - & LAOP01000001 \\
\hline "R. felis" & LSU & 1.54 & 32.4 & $\mathrm{pRF}$ & 1970 & - & - & JSEM01000001 \\
\hline "R. felis" & LSU lb & 1.58 & 32.4 & pRF, pLbaR & 1691 & - & - & JSEL01000001 \\
\hline "R. felis" & Pedreira & 1.49 & 32.5 & & 1594 & - & - & LANQ01000001 \\
\hline "R. felis" & URRWXCal2 & 1.49 & 32.5 & $\mathrm{pRF}, \mathrm{pRF} \delta$ & 1444 & $83.6 \%$ & 726 & NC_007109 \\
\hline R. gravesii & BWI-1 & 1.37 & 32.2 & pRgr & 1158 & - & - & AWXL01000001 \\
\hline R. heilongjiangensis & O54 & 1.28 & 32.3 & & 1140 & - & - & СР002912 \\
\hline R. helvetica & С9P9 & 1.37 & 32.2 & pRhe & 1114 & - & - & CM001467 \\
\hline R. honei & $R B$ & 1.27 & 32.4 & & 1171 & - & - & AJTT01000001 \\
\hline R. hoogstraalii & Croatica & 1.48 & 32.4 & & 1250 & - & - & CCXM01000001 \\
\hline R. hoogstraalii & RCCE3 & 2.3 & 32.4 & & 2479 & - & - & LAOB01000001 \\
\hline R. japonica & $Y H$ & 1.28 & 32.4 & & 1142 & - & - & NC_016050 \\
\hline R. massiliae & AZT80 & 1.28 & 32.5 & $\mathrm{pRmaB}$ & 1207 & - & - & NC_016931 \\
\hline R. massiliae & MTU5 & 1.37 & 32.5 & pRma & 1152 & - & 565 & NC_009900 \\
\hline "R. monacensis" & IrR/Munich & 1.35 & 32.4 & $\mathrm{pRM}$ & 1447 & - & - & NZ_LN794217 \\
\hline R. montanensis & OSU 85-930 & 1.28 & 32.6 & & 1125 & - & - & СР003340 \\
\hline R. parkeri & AT\#24 & 1.3 & 32.4 & & 1226 & - & - & LAOL01000001 \\
\hline R. parkeri & GrandBay & 1.31 & 32.4 & & 1223 & - & - & LAOK01000001 \\
\hline R. parkeri & Portsmouth & 1.3 & 32.4 & & 1228 & - & - & NC_017044 \\
\hline R. parkeri & TatesHell & 1.3 & 32.4 & & 1227 & - & - & LAOO01000001 \\
\hline R. peacockii & Rustic & 1.29 & 32.6 & pRpe & 927 & - & - & СР001227 \\
\hline "R. philipii" & $364 \mathrm{D}$ & 1.29 & 32.5 & & 1218 & - & - & СР003308 \\
\hline R. prowazekii & Breinl & 1.11 & 29 & & 842 & - & - & NC_020993 \\
\hline R. prowazekii & BuV67-CWPP & 1.11 & 29 & & 843 & - & - & NC_017056 \\
\hline R. prowazekii & Cairo3 & 1.11 & 29 & & 842 & - & - & APMO01000001 \\
\hline R. prowazekii & Chernikova & 1.11 & 29 & & 845 & - & - & NC_017049 \\
\hline R. prowazekii & Dachau & 1.11 & 29 & & 839 & - & - & NC_017051 \\
\hline R. prowazekii & GvV257 & 1.11 & 29 & & 829 & - & - & NC_017048 \\
\hline R. prowazekii & Katsinyian & 1.11 & 29 & & 844 & - & - & NC_017050 \\
\hline R. prowazekii & Madrid E & 1.11 & 29 & & 834 & $75.4 \%$ & 120 & NC_-000963 \\
\hline R. prowazekii & NMRC Madrid E & 1.11 & 29 & & 830 & - & - & NC_020992 \\
\hline R. prowazekii & $\mathrm{Rp} 22$ & 1.11 & 29 & & 864 & $76.2 \%$ & - & NC_-017560 \\
\hline R. prowazekii & RpGvF24 & 1.11 & 29 & & 870 & - & - & NC_017057 \\
\hline R. raoultii & Khabarovsk & 1.34 & 32.8 & pRa1, pRa2, pRa3, pRa4 & 1334 & - & - & CP010969 \\
\hline R. rhipicephali & 3-7-female 6-CWPP & 1.31 & 32.4 & pRrh & 1117 & - & - & NC_017042 \\
\hline R. rhipicephali & Ect & 1.27 & 32.6 & & 1067 & - & - & LAOC01000001 \\
\hline R. rhipicephali & HJ\#5 & 1.45 & 32.3 & pHJ51, pHJ52 & 1200 & - & - & NZ_CP013133 \\
\hline
\end{tabular}


Table 2 (continued)

\begin{tabular}{|c|c|c|c|c|c|c|c|c|}
\hline Species & Strain & $\begin{array}{l}\text { Genome } \\
\text { size }(\mathrm{Mbp})\end{array}$ & $\begin{array}{l}\mathrm{G}+\mathrm{C} \\
\text { content }(\%)\end{array}$ & Presence of plasmid (s) & $\begin{array}{l}\text { Protein-coding } \\
\text { genes }\end{array}$ & $\begin{array}{l}\% \text { coding } \\
\text { sequences }\end{array}$ & $\begin{array}{l}\text { Rickettsia } \\
\text { palindromic } \\
\text { elements }\end{array}$ & $\begin{array}{l}\text { Chromosome } \\
\text { accession } \\
\text { number }\end{array}$ \\
\hline R. rickettsii & Arizona & 1.27 & 32.4 & & 1343 & - & - & NC_016909 \\
\hline R. rickettsii & Brazil & 1.25 & 32.4 & & 1339 & - & - & NC_016913 \\
\hline R. rickettsii & Colombia & 1.27 & 32.4 & & 1342 & - & - & NC_016908 \\
\hline R. rickettsii & Hauke & 1.27 & 32.4 & & 1347 & - & - & NC_016911 \\
\hline R. rickettsii & Hino & 1.27 & 32.4 & & 1346 & - & - & NC_016914 \\
\hline R. rickettsii & Hlp\#2 & 1.27 & 32.4 & & 1339 & - & - & NC_016915 \\
\hline R. rickettsii & Iowa & 1.27 & 32.4 & & 1384 & - & - & NC_010263 \\
\hline R. rickettsii & Morgan & 1.27 & 32.4 & & 1343 & - & - & NZ_CP006010 \\
\hline R. rickettsii & $\mathrm{R}$ & 1.26 & 32.4 & & 1334 & - & - & NZ_CP006009 \\
\hline R. rickettsii & Sheila Smith & 1.26 & 32.5 & & 1345 & $78.5 \%$ & - & NC_009882 \\
\hline R. sibirica & 246 & 1.25 & 32.5 & & 1227 & $77.8 \%$ & - & AABW01000001 \\
\hline R. sibirica & HA-91 & 1.25 & 32.4 & & 1175 & - & - & AHZB01000001 \\
\hline R. sibirica & BJ-90 & 1.25 & 32.4 & & 1217 & - & - & AHIZ01000001 \\
\hline R. slovaca & D-CWPP & 1.27 & 32.5 & & 1261 & - & - & NC_017065 \\
\hline R. slovaca & 13-B & 1.27 & 32.5 & & 1260 & - & - & NC_016639 \\
\hline R. tamurae & AT-1 & 1.44 & 32.4 & Plasmid 1, Plasmid 2 & 1200 & - & - & CCMG01000008 \\
\hline R. typhi & B9991CWPP & 1.11 & 28.9 & & 819 & - & - & NC_017062 \\
\hline R. typhi & TH1527 & 1.11 & 28.9 & & 819 & - & - & NC_017066 \\
\hline R. typhi & Wilmington & 1.11 & 28.9 & & 817 & $76.3 \%$ & 121 & NC_006142 \\
\hline
\end{tabular}

Species with as yet no standing in nomenclature are written with quotation marks $(-)=$ no available data.

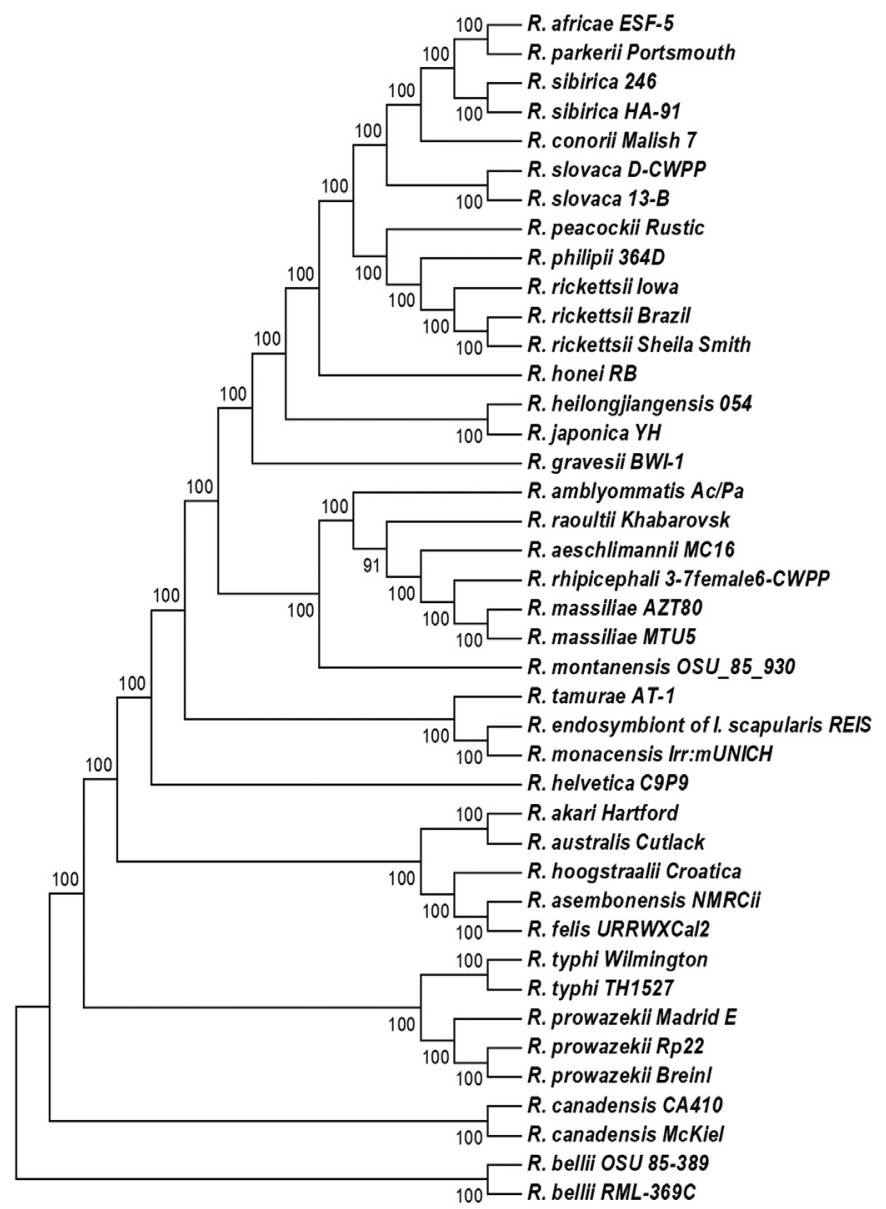

Fig. 1. Phylogenetic tree of 31 Rickettsia species with validly published names based on the alignment of 450 concatenated core proteins using the Maximum Likelihood method with JTT and GAMMA models and display only topology. Values at the nodes represent the percentages of bootstrap values obtained by repeating analysis 500 times to generate a majority consensus tree. Only values greater than $70 \%$ were indicated.

\section{Comparative analysis of rickettsial genomes}

The first genomic comparison of Rickettsia species was that of the first two sequenced genomes from Rickettsia conorii and $R$. prowazekii [22]. This study showed a near perfect colinearity between both species (Fig. 2) but the latter species had a smaller genome and a higher proportion of non coding DNA, including many pseudogenes. Further comparisons confirmed this trend in genomic reduction $(1.5-1.1 \mathrm{Mb}$, coding capacity $69-84 \%$ ) through progressive gene degradation until complete disappearance [28]. Degraded genes include mostly those coding for amino-acid, ATP, LPS and cell wall component biosynthesis [14,22,29].

Comparative genomic analysis of Rickettsia species revealed variations in chromosome size and plasmid number and size (Table 2), despite a common ongoing reductive evolution [30] by progressive gene loss and concomitant gene gain by gene duplication, proliferation of RPEs and horizontal gene transfer [4]. Gene family duplication is frequent in rickettsial genomes and is thought to enable adaptation to environmental changes in the host. The two most duplicated genes encode ADP/ATP translocases, often found in several copies and enabling energy exploitation produced by host cells [29,31], and spoT genes found in 4-14 copies and involved in the microbial response to environmental stress [24,29,32]. Other duplicated gene families include proline/betaine transporters, toxin/antitoxin modules, T4SS, sca and ampG involved in rickettsial pathogenesis as previously described $[17,22,29,33]$. Rickettsiae possess an incomplete P-T4SS system that is characterized by the lack of virB5 but the duplication of the virB4, virB6, virB8 and virB9 genes [34]. Surface cell antigen (Sca) proteins are a family of 17 orthologous autotransporters diversely detected in all rickettsial genomes [33]. They were demonstrated to be localized at the 


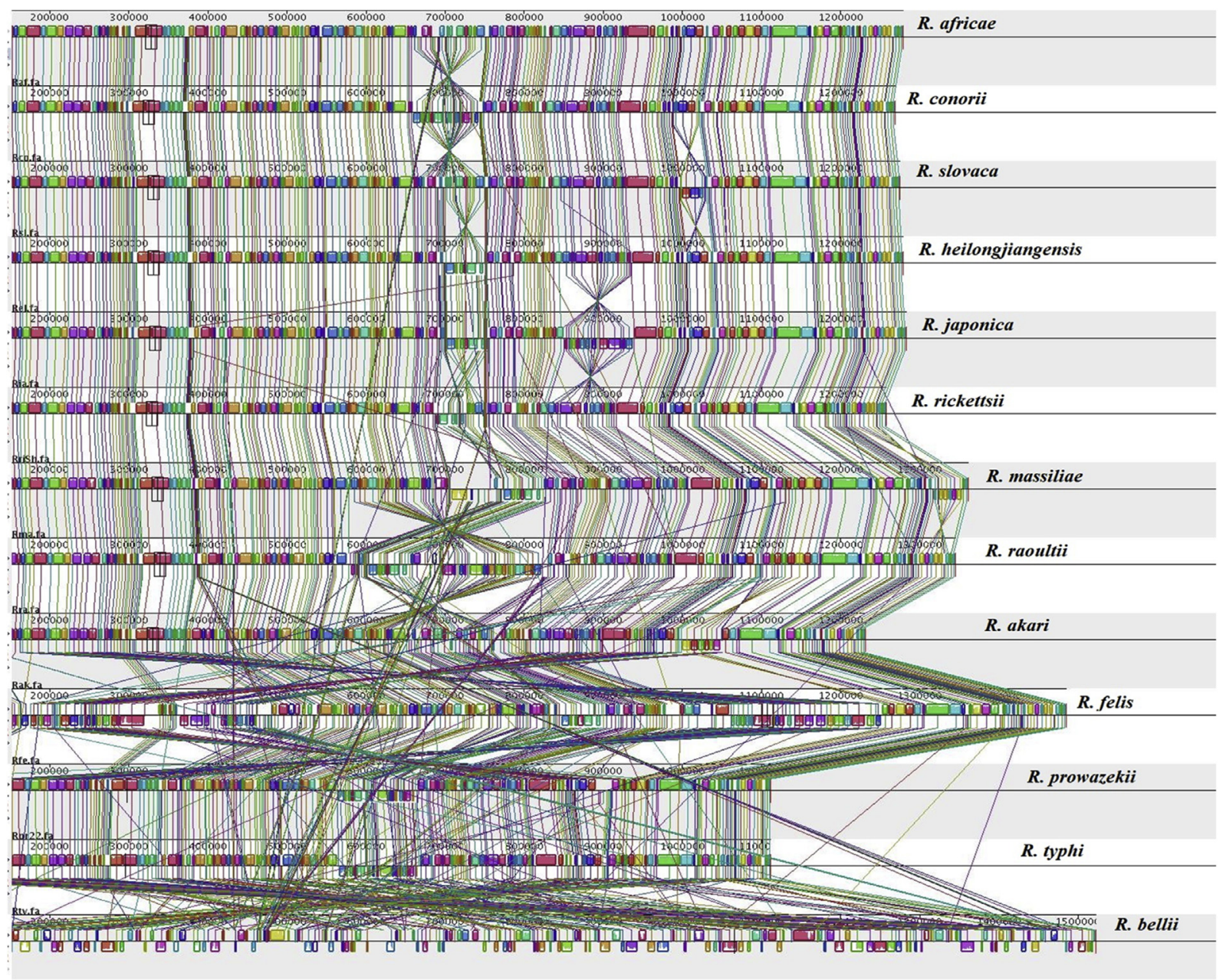

Fig. 2. Genomic alignment showing the high degree of conserved genomic synteny between Rickettsia species.

surface of bacteria and play roles in mammalian cell infection as well as infecting their arthropod hosts' cells, notably by promoting actin-based motility [35], In addition, many repetitive elements are distributed in intergenic regions (tandem repeats) [36] or both intergenic and coding regions (RPEs) $[37,38]$. RPEs are at least five times more numerous in SFG rickettsia than in TG rickettsia (Table 2). They are assumed to play a role in the evolution of rickettsial genomes by promoting the emergence of new proteins [39]. Twenty-two copies of ankyrin and 11 copies of tetratricopeptide repeats (TPR-repeat), frequently found in endosymbionts [40-43] are found in $R$. felis [44]. Finally, plasmids are less abundant in virulent than less virulent species $[8,24,45]$. They were most likely acquired vertically from Orientia/Rickettsia chromosome ancestors [27]. The genome from REIS, the largest rickettsial genome to date, is characterized by a remarkable proliferation of mobile genetic elements $(35 \%$ of the entire genome) including a RAGE module considered as a genetic exchange facilitators [46] and resulting from multiplied genomic invasion events [13]. It was also described in Orientia tsutsugamushi, Rickettsia massiliae [25], R. bellii [47] and in the pLbaR plasmid of $R$. felis strain LSU-Lb [48]. Several genes including tra cluster, T4SS, ADP/ATP translocases and patatin-encoding genes found in Rickettsia spp. are phylogenetically close to those found in many amoeba-associated bacteria, suggesting their acquisition by horizontal transfer events between Rickettsia and non-rickettsial bacteria $[4,47]$.

Other lessons from rickettsial genome comparison are the identification of 15-191 small non-coding RNAs (sRNAs) in intergenic sequences, depending on species [49]. These posttranscriptional regulators are assumed to influence virulence and adaptation depending on the host niche through transcriptomic regulation [49]. Their presence may explain why early comparative studies had identified highly conserved intergenic spacers [22]. A total of 1785 sRNAs were detected from 13 species spanning all rickettsial groups, and the expression of sRNAs was demonstrated in $R$. prowazekii [49]. In addition, all five genes required for the de novo folate biosynthesis were demonstrated to be present in 15 Rickettsia species, including both human pathogens and non pathogens but excluding the typhus group [50].

Finally, comparative genomics at the intraspecies level enabled identification of variable situations [51]. In Rickettsia japonica, 31 strains from the three major lineages exhibited only 112 single nucleotide polymorphisms (SNPs) and 44 InDels, thus suggesting a long generation time in nature or a 
recent clonal expansion [51]. In $R$. prowazekii, similar findings were identified, with 81 SNPs observed among 3 strains [51]. In Rickettsia rickettsii, the comparison of 4 strains, two eastern an two western strains showed geographic divergences but an overall high genetic homology with few differences in coding regions [52]. This study also demonstrated that the avirulent strain Iowa only diverged from virulent strains by 29 SNPs in addition to a 891-bp insertion in the ompA gene [52]. In contrast, the comparison of $3 \mathrm{R}$. felis strains, including two from cat fleas and one from book lice, demonstrated that not only was the book louse strain divergent, with a unique plasmid and SNPs occurring in intergenic regions, RPEs and conserved Rickettsia genes, but also were both cat flea strains which exhibited SNPs in genes associated to the Rickettsia mobilome [48]. These data suggest that the observed difference may result from spatial isolation for cat flea strains and host specialization in the case of the book louse strain.

\section{Paradigm of genome reduction associated with increased virulence}

For long, it was believed that bacteria gain virulence by the acquisition of foreign genetic material. However, the comparison of the $R$. prowazekii and $R$. conorii genomes demonstrated that the former species, which is the most virulent, has a drastically degradated genome [19]. Further studies demonstrated that, in Rickettsia spp., some speculated virulence factors were found in both pathogenic and nonpathogenic bacteria, and genomes from the most pathogenic species were found to have few or no additional genes when compared to closely related but lesser pathogens. In addition, no association was found between virulence and the presence of plasmids or gene acquisition [45]. R. prowazekii, the most pathogenic Rickettsia species and agent of epidemic typhus has the smallest genome and an inverse correlation exists between genome size and degree of pathogenicity [21]. These findings suggested a new paradigm in rickettsial pathogenicity that linked increased virulence to genome reductive evolution rather than virulence gene acquisition. Comparative genomics showed a loss of nonessential genes including genes coding for the amino acid synthesis and biosynthetic pathway components during reductive evolution [53]. The most virulent $R$. prowazekii has lost transcriptional regulator genes with a decreased translational capacity [54], but conserved genes coding for toxins, toxin-antitoxin (TA) modules and recombination and DNA repair proteins most likely needed for protection against host immune response [55]. In addition, recent multi-omics data showed a link between reductive evolution and differential gene expression between two virulent and two less virulent SFG rickettsiae. The two virulent R. conorii (MSF) and Rickettsia slovaca (SENLAT) agents exhibit less up-regulated than down-regulated genes and than the less virulent $R$. massiliae (MSF) and Rickettsia raoultii (SENLAT) agents [8]. The former two species have more reduced genomes with plasmid loss than the latter two, suggesting that reductive genomic evolution associated with increased virulence may not be only a question of presence or lack of a specific protein but may also result from differential level or degradation of expression of common proteins [8]. It was speculated that loss of regulator genes, as observed in several intracellular pathogens, is a critical cause of virulence [45].

This phenomenon was also observed in other human pathogens not genetically related to Rickettsia species such as Treponema spp., Mycobacterium spp. or Yersinia spp. $[16,20,56]$. As examples, Mycobacterium leprae, Treponama pallidum and Yersinia pestis have smaller genomes than closely related but less virulent species in their respective genera. Thus, genomic reductive evolution with alteration of the regulation of invasion, replication and transmission processes, in addition to a differential level or degradation of expression of common proteins may result in an emergence of high pathogenicity.

\section{Identified virulence factors in rickettsial genomes}

Predicting virulence factors from genome sequences has been among the first objectives of genomics, especially for intracellular bacteria expressing few phenotypic characters. Therefore, several studies were conducted to compare rickettsial species or strains exhibiting diverse virulence phenotypes in order to identify pathogenesis factors. Surprisingly, no association was found between pathogenesis and the acquision of novel virulence genes $[17,21,45]$. In contrast, outer membrane proteins, notably $\mathrm{Sca} 2$ in $R$. rickettsii, and ankyrin repeat-coding genes were demonstrated to be essential virulence determinants $[43,57]$. However, RelA/SpoT responsible for the synthesis and hydrolysis of (p)ppGpp [58] and RickA, involved in actin-based bacterial motility [22] were found in both avirulent and virulent $R$. rickettsii strains and were thus ruled out as essential pathogenesis determinants [57]. In $R$. prowazekii, three virulence markers were identified through genome comparison, including recO $O$, involved in DNA repair, $m e t K$ and $a d r l$ encoding a S-adenosyl-methonine synthase and an adhesin, respectively, which are mutated in avirulent strains [53]. In addition, the RalF protein, a T4SS effector coded by genes conserved in all species, was demonstrated to play a role in host cell invasion in $R$. typhi, in contrast with SFG species in which it is pseudogenized [59].

\section{Role of rickettsial plasmids in virulence}

The presence of plasmids in Rickettsia genomes was first detected in that of R. felis [24]. To date, plasmids have been detected in 11 Rickettsia species [27]. Rickettsial plasmids result from vertical inheritance, mainly from Orientia/Rickettsia chromosome ancestors [27]. However, plasmids vary in number within and between species [27,60,61]. A variable plasmid content was observed in strains of Rickettsia africae, R. bellii, Rickettsia akari, Rickettsia amblyommatis and R. felis $[21,60,61]$. In addition, plasmid loss was demonstrated in cell culture [61]. As plasmids were present in several pathogenic species and contained protein-encoding genes necessary for recognition, invasion and pathogenicity, their role in rickettsial 
virulence was questioned [27]. However, the unstable plasmid content of $R$. africae did not support a role of plasmid in virulence in this species [21]. Furthermore, a strong correlation was observed between plasmid and genome sizes, with a paralleling decrease existing between plasmid size, number, and chromosome size. As examples, several species causing mild or no disease, such as the SFG Rickettsia helvetica, R. felis, and Rickettsia peacockii, possess one or more plasmids $[21,24,43]$ whereas the most virulent species $R$. prowazekii and $R$. typhi that exhibit the most reduced genomes are plasmidless $[15,52,53]$. Furthermore, a recent multi-omics-study that compared four SFG rickettsiae showed that $R$. conorii and $R$. slovaca, the agents of MSF and SENLAT, respectively, were plasmidless but $R$. massiliae and $R$. raoultii, two less virulent agents of these diseases, harbor one and three plasmids, respectively [8]. Moreover, plasmids were also shown to undergo reductive evolutionary events similar to those affecting rickettsial chromosomes [27]. These findings support the absence of association between the presence of plasmids and difference in virulence in Rickettsia species.

\section{Transcriptomic and proteomic investigation of rickettsial virulence}

To date, several studies have demonstrated that transcriptomic and proteomic results are complementary to genomic analyses for analyzing bacterial virulence. A proteomic analysis of Rickettsia parkeri revealed that 91 proteins, including mostly virulence-related surface proteins (OmpA, OmpB, $\beta$-peptide, RickA), were differentially expressed during human infection [62]. Proteomic profile comparison of $R$. prowazekii grown in different cell lines, revealed an upregulation of stress-related proteins in L929 murine fibroblasts [63]. In addition, proteins involved in protein synthesis, especially enoyl-(acyl carrier protein) reductase, a protein involved in fatty acid biosynthesis, were highly expressed when grown in I. scapularis ISE6 cells, suggesting that this rickettsia has the ability to regulate differentially its proteome according to the host [63]. Using transcriptomic and proteomic analyses of virulent and avirulent $R$. prowazekii strains, we identified four phenotypes that differed in virulence depending on the regulation of anti-apoptotic genes or the interferon I pathway in host cells [53]. Furthermore, $R$. prowazekii protein methylation (overproduced in virulent strains) and surface protein expression (Adr1 altered in avirulent Madrid E) varied with virulence, supporting the assumption that methylation of surface-exposed protein plays a role in the virulence of $R$. prowazekii [53]. In addition, in a recent proteomic and transcriptomic study, we compared two virulent agents, $R$. conorii and $R$. slovaca, causing MSF and SENLAT diseases, respectively, to two less virulent agents of the same diseases (R. massiliae and $R$. raoultii, respectively) [8]. Virulent species differed from less virulent ones by exhibiting mainly less up-regulated (8) than down-regulated (61) proteins. These included proteins associated mainly with translation, ribosomal structure and biogenesis, post-translational modification, protein turnover, chaperones, energy production and conversion [8]. In addition, virulent agents had rarely specifically expressed proteins [8]. This provides novel insights into the pathogenesis of Rickettsia species and suggests that virulence may not only be a question of presence or lack of a specific protein but may also result from a differential level or degradation of expression of a common protein.

\section{Conclusion and perspective}

Rickettsia spp., living mainly intracellularly in various arthropods, have undergone a particular paradoxical evolution marked by an evolutive chromosomic and plasmidic degradation resulting in a progressive genome reduction from 1.5 to $1.1 \mathrm{Mb}$ with a coding capacity of $69-84 \%$. This reductive evolution is marked by a selected loss of genes such as those associated with ATP, amino-acid and LPS metabolism or with synthesis of cell wall molecular components. In addition, a loss of regulatory genes and a high preservation of toxinassociated proteins and toxin-antitoxin modules are correlated to a rise in pathogenicity. However, paradoxically, these bacteria have undergone a proliferation of genetic elements whose role remains to be determined. As proteomic and transcriptomic analyses have just started to unveil the molecular mechanisms explaining the differences in virulence among Rickettsia species, and because the phenomenon of genome reduction associated with increased virulence seems to occur in other major human pathogens, these being examples of convergent evolution, i. e. natural selection leading to a similar biological outcome occurring independently in more than one unrelated biological group, future studies should identify which of the differences in rickettsial genomes account for their phenotypes.

\section{Conflict of interest}

The authors declare no conflict of interest.

\section{Acknowledgments}

This study was funded by the Mediterranee Infection Foundation and the French Agence Nationale de la Recherche under reference Investissements d'avenir Méditerranée Infection 10-IAHU-03.

\section{References}

[1] Stothard DR, Clark JB, Fuerst PA. Ancestral divergence of Rickettsia bellii from the spotted fever and typhus groups of Rickettsia and antiquity of the genus Rickettsia. Int J Syst Evol Microbiol 1994;44:798-804.

[2] Raoult D, Roux V. Rickettsioses as paradigms of new or emerging infectious diseases. Clin Microbiol Rev 1997;10:694-719.

[3] Gillespie JJ, Beier MS, Rahman MS, Ammerman NC, Shallom JM, Purkayastha A, et al. Plasmids and rickettsial evolution: insight from Rickettsia felis. PLos One 2007;2:e266.

[4] Merhej V, Raoult D. Rickettsial evolution in the light of comparative genomics. Biol Rev 2011;86:379-405.

[5] Merhej V, Angelakis E, Socolovschi C, Raoult D. Genotyping, evolution and epidemiological findings of Rickettsia species. Infect Genet Evol 2014;25:122-37. 
[6] Parola P, Paddock CD, Socolovschi C, Labruna MB, Mediannikov O, Kernif T, et al. Update on tick-borne Rickettsioses around the world: a geographic approach. Clin Microbiol Rev 2013;26:657-702.

[7] Sahni SK, Narra HP, Sahni A, Walker DH. Recent molecular insights into rickettsial pathogenesis and immunity. Future Microbiol 2013;8:1265-88.

[8] El Karkouri K, Kowalczewska M, Armstrong N, Azza S, Fournier P-E, Raoult D. Multi-omics analysis sheds light on the evolution and the intracellular lifestyle strategies of spotted fever group Rickettsia spp. Front Microbiol 2017;8.

[9] Weinert LA, Werren JH, Aebi A, Stone GN, Jiggins FM. Evolution and diversity of Rickettsia bacteria. BMC Biol 2009;7:6.

[10] Murray GGR, Weinert LA, Rhule EL, Welch JJ. The phylogeny of Rickettsia using different evolutionary signatures: how tree-like is bacterial evolution? Syst Biol 2016;65:265-79.

[11] Fleischmann R, Adams M, White O, Clayton R, Kirkness E, Kerlavage A, et al. Whole-genome random sequencing and assembly of Haemophilus influenzae Rd. Science 1995;269:496-512.

[12] Balraj P, Renesto P, Raoult D. Advances in Rickettsia pathogenicity. Ann N Y Acad Sci 2009;1166:94-105.

[13] Gillespie JJ, Joardar V, Williams KP, Driscoll T, Hostetler JB, Nordberg E, et al. A Rickettsia genome overrun by mobile genetic elements provides insight into the acquisition of genes characteristic of an obligate intracellular lifestyle. J Bacteriol 2012;194:376-94.

[14] Blanc G, Ogata H, Robert C, Audic S, Suhre K, Vestris G, et al. Reductive genome evolution from the mother of Rickettsia. PLoS Genet 2007;3:e14.

[15] McLeod MP, Qin X, Karpathy SE, Gioia J, Highlander SK, Fox GE, et al. Complete genome sequence of Rickettsia typhi and comparison with sequences of other rickettsiae. J Bacteriol 2004;186:5842-55.

[16] Merhej V, Royer-Carenzi M, Pontarotti P, Raoult D. Massive comparative genomic analysis reveals convergent evolution of specialized bacteria. Biol Direct 2009;4:13.

[17] Georgiades K, Raoult D. Genomes of the most dangerous epidemic bacteria have a virulence repertoire characterized by fewer genes but more toxin-antitoxin modules. PLos One 2011;6:e17962.

[18] Andersson SG, Zomorodipour A, Andersson JO, Sicheritz-Pontén T, Alsmark UCM, Podowski RM, et al. The genome sequence of Rickettsia prowazekii and the origin of mitochondria. Nature 1998;396:133-40.

[19] Sakharkar KR. Genome reduction in prokaryotic obligatory intracellular parasites of humans: a comparative analysis. Int J Syst Evol Microbiol 2004;54:1937-41.

[20] Walker DH. Progress in rickettsial genome analysis from pioneering of Rickettsia prowazekii to the recent Rickettsia typhi. Ann N Y Acad Sci 2005;1063:13-25.

[21] Fournier P-E, El Karkouri K, Leroy Q, Robert C, Giumelli B, Renesto P, et al. Analysis of the Rickettsia africae genome reveals that virulence acquisition in Rickettsia species may be explained by genome reduction. BMC Genomics 2009;10:166.

[22] Ogata H. Mechanisms of evolution in Rickettsia conorii and R. prowazekii. Science 2001;293:2093-8.

[23] Ogata H, Audic S, Abergel C, Fournier P-E, Claverie J-M. Protein coding palindromes are a unique but recurrent feature in Rickettsia. Genome Res 2002; $12: 808-16$.

[24] Ogata H, Renesto P, Audic S, Robert C, Blanc G, Fournier P-E, et al. The genome sequence of Rickettsia felis identifies the first putative conjugative plasmid in an obligate intracellular parasite. PLoS Biol 2005;3: e248.

[25] Blanc G, Ogata H, Robert C, Audic S, Claverie J-M, Raoult D. Lateral gene transfer between obligate intracellular bacteria: evidence from the Rickettsia massiliae genome. Genome Res 2007;17:1657-64.

[26] Baldridge GD, Burkhardt NY, Felsheim RF, Kurtti TJ, Munderloh UG. Transposon insertion reveals pRM, a plasmid of Rickettsia monacensis. Appl Environ Microbiol 2007;73:4984-95.

[27] El Karkouri K, Pontarotti P, Raoult D, Fournier P-E. Origin and evolution of rickettsial plasmids. PLos One 2016;11:e0147492.

[28] Merhej V, Georgiades K, Raoult D. Postgenomic analysis of bacterial pathogens repertoire reveals genome reduction rather than virulence factors. Brief Funct Genomics 2013;12:291-304.
[29] Renesto P, Ogata H, Audic S, Claverie J-M, Raoult D. Some lessons from Rickettsia genomics. FEMS Microbiol Rev 2005;29:99-117.

[30] Andersson JO, Andersson SG. Genome degradation is an ongoing process in Rickettsia. Mol Biol Evol 1999;16:1178-91.

[31] Greub G, Raoult D. History of the ADP/ATP-translocase-encoding gene, a parasitism gene transferred from a Chlamydiales ancestor to plants 1 billion years ago. Appl Environ Microbiol 2003;69:5530-5.

[32] Rovery C, Renesto P, Crapoulet N, Matsumoto K, Parola P, Ogata H, et al. Transcriptional response of Rickettsia conorii exposed to temperature variation and stress starvation. Res Microbiol 2005;156:211-8.

[33] Blanc G. Molecular evolution of Rickettsia surface antigens: evidence of positive selection. Mol Biol Evol 2005;22:2073-83.

[34] Gillespie JJ, Phan IQH, Driscoll TP, Guillotte ML, Lehman SS, RennollBankert KE, et al. The Rickettsia type IV secretion system: unrealized complexity mired by gene family expansion. Pathol Discov 2016;74: ftw058.

[35] Sears KT, Ceraul SM, Gillespie JJ, Allen ED, Popov VL, Ammerman NC, et al. Surface proteome analysis and characterization of surface cell antigen (Sca) or autotransporter family of Rickettsia typhi. PLoS Pathog 2012;8:e1002856.

[36] Fournier P-E, Zhu Y, Ogata H, Raoult D. Use of highly variable intergenic spacer sequences for multispacer typing of Rickettsia conorii strains. J Clin Microbiol 2004;42:5757-66.

[37] Amiri H, Alsmark CM, Andersson SG. Proliferation and deterioration of Rickettsia palindromic elements. Mol Biol Evol 2002;19:1234-43.

[38] Ogata H, Audic S, Barbe V, Artiguenave F, Fournier PE, Raoult D, et al. Selfish DNA in protein-coding genes of Rickettsia. Science 2000;290: 347-50.

[39] Claverie J-M, Ogata H. The insertion of palindromic repeats in the evolution of proteins. Trends Biochem Sci 2003;28:75-80.

[40] Seshadri R, Paulsen IT, Eisen JA, Read TD, Nelson KE, Nelson WC, et al. Complete genome sequence of the Q-fever pathogen Coxiella burnetii. Proc Natl Acad Sci U S A 2003;100:5455-60.

[41] Caturegli P, Asanovich KM, Walls JJ, Bakken JS, Madigan JE, Popov VL, et al. ankA: an Ehrlichia phagocytophila group gene encoding a cytoplasmic protein antigen with ankyrin repeats. Infect Immun 2000;68:5277-83.

[42] Wu M, Sun LV, Vamathevan J, Riegler M, Deboy R, Brownlie JC, et al. Phylogenomics of the reproductive parasite Wolbachia pipientis wMel: a streamlined genome overrun by mobile genetic elements. PLoS Biol 2004;2:e69.

[43] Felsheim RF, Kurtti TJ, Munderloh UG. Genome sequence of the endosymbiont Rickettsia peacockii and comparison with virulent Rickettsia rickettsii: identification of virulence factors. PLos One 2009;4: e8361.

[44] Ogata H. Rickettsia felis, from culture to genome sequencing. Ann N Y Acad Sci 2005;1063:26-34.

[45] Darby AC, Cho N-H, Fuxelius H-H, Westberg J, Andersson SGE. Intracellular pathogens go extreme: genome evolution in the Rickettsiales. Trends Genet 2007;23:511-20.

[46] Gillespie JJ, Kaur SJ, Rahman MS, Rennoll-Bankert K, Sears KT, BeierSexton M, et al. Secretome of obligate intracellular Rickettsia. FEMS Microbiol Rev 2015;39:47-80.

[47] Ogata H, La Scola B, Audic S, Renesto P, Blanc G, Robert C, et al. Genome sequence of Rickettsia bellii illuminates the role of Amoebae in gene exchanges between intracellular pathogens. PLoS Genet 2006;2:e76.

[48] Gillespie JJ, Driscoll TP, Verhoeve VI, Utsuki T, Husseneder C, Chouljenko VN, et al. Genomic diversification in strains of Rickettsia felis isolated from different arthropods. Genome Biol Evol 2015;7: $35-56$.

[49] Schroeder CLC, Narra HP, Rojas M, Sahni A, Patel J, Khanipov K, et al. Bacterial small RNAs in the genus Rickettsia. BMC Genomics 2015;16.

[50] Hunter DJ, Torkelson JL, Bodnar J, Mortazavi B, Laurent T, Deason J, et al. The Rickettsia endosymbiont of Ixodes pacificus contains all the genes of de novo folate biosynthesis. PLos One 2015;10:e0144552.

[51] Akter A, Ooka T, Gotoh Y, Yamamoto S, Fujita H, Terasoma F, et al. Extremely low genomic diversity of Rickettsia japonica distributed in Japan. Genome Biol Evol 2017:evw304. 
[52] Clark TR, Noriea NF, Bublitz DC, Ellison DW, Martens C, Lutter EI, et al. Comparative genome sequencing of Rickettsia rickettsii strains that differ in virulence. Infect Immun 2015;83:1568-76.

[53] Bechah Y, El Karkouri K, Mediannikov O, Leroy Q, Pelletier N, Robert C, et al. Genomic, proteomic, and transcriptomic analysis of virulent and avirulent Rickettsia prowazekii reveals its adaptive mutation capabilities. Genome Res 2010;20:655-63.

[54] Andersson SG, Kurland CG. Reductive evolution of resident genomes. Trends Microbiol 1998;6:263-8.

[55] Moran NA. Microbial minimalism: genome reduction in bacterial pathogens. Cell 2002;108:583-6.

[56] Wixon J. Featured organism: reductive evolution in bacteria: Buchnera sp., Rickettsia prowazekii and Mycobacterium leprae. Comp Funct Genomics 2001;2:44-8.

[57] Ellison DW, Clark TR, Sturdevant DE, Virtaneva K, Porcella SF, Hackstadt T. Genomic comparison of virulent Rickettsia rickettsii Sheila Smith and avirulent Rickettsia rickettsii Iowa. Infect Immun 2008;76: $542-50$
[58] Clark TR, Ellison DW, Kleba B, Hackstadt T. Complementation of Rickettsia rickettsii RelA/SpoT restores a nonlytic plaque phenotype. Infect Immun 2011;79:1631-7.

[59] Rennoll-Bankert KE, Rahman MS, Gillespie JJ, Guillotte ML, Kaur SJ, Lehman SS, et al. Which way in? The RalF Arf-GEF orchestrates Rickettsia host cell invasion. PLoS Pathog 2015;11:e1005115.

[60] Baldridge GD, Burkhardt NY, Felsheim RF, Kurtti TJ, Munderloh UG. Plasmids of the pRM/pRF family occur in diverse Rickettsia species. Appl Environ Microbiol 2008;74:645-52.

[61] Fournier P-E, Belghazi L, Robert C, Elkarkouri K, Richards AL, Greub G, et al. Variations of plasmid content in Rickettsia felis. PLos One 2008:3:e2289.

[62] Pornwiroon W, Bourchookarn A, Paddock CD, Macaluso KR. Proteomic analysis of Rickettsia parkeri strain Portsmouth. Infect Immun 2009;77: 5262-71.

[63] Tucker AM, Driskell LO, Pannell LK, Wood DO. Differential proteomic analysis of Rickettsia prowazekii propagated in diverse host backgrounds. Appl Environ Microbiol 2011;77:4712-8. 